\title{
Evaluation of Chrysanthemum morifolium cv. Maghi plants after sodium azide treatment
}

\author{
M. A-H. Mohamed ${ }^{1}$, Aly M.K ${ }^{1}$, Mostafa G.G. ${ }^{2}{ }^{*}$ and Abd Alaziz H.R. ${ }^{3}$ \\ ${ }^{1}$ Department of Horticulture, Fac. of Agriculture, Minia University,Egypt. \\ ${ }^{2}$ Horticulture Department, Faculty of Agriculture, Beni-Suef University,Beni-Suef,Egypt. \\ ${ }^{3}$ Horticulture Department, Faculty of Agriculture, South Valley University, Egypt. \\ *corresponding author: e-mail: gehangaber2006@yahoo.com
}

\begin{abstract}
The present study was carried out during two successive seasons 2015/2016 and 2016/2017 to study the genetic variability of some growth and flowering traits of Chrysanthemum morifolium $\mathrm{cv}$. Maghi plants caused by Sodium Azide (SA) treatments. Shoot apical cuttings were dipped in the SA solution, at $0.0,0.12$ and $0.18 \%$ for two different soaking times $(6$ and $12 \mathrm{~h})$. The cutting survivability was immensely hampered $(\mathrm{P}>0.05)$ due to the SA concentrations and the time of the treatment.

In both seasons, there were remarkable variations in the range of all investigated traits due to the SA treatments such as plant height, number of branches and flower heads/plant, Flower head diameters and their fresh and dry weight. However, number of days till full blooming showed the lowest variation. All SA-treated plants had higher PCV and GCV than the control ones for all investigated traits except days to full bloom and flower head fresh weights. Moreover, The PCV was always higher than GCV for all the characters. Almost all traits had higher heritability. However, there were huge differences in heritability values between the control and SA-treated plants. Presence of narrow gap between phenotypic coefficient of variation and genotypic coefficient of variation for many the characters under the study suggested that expression of these traits studied showed low environmental influence, which provide ample scope for selection of superior and desired mutants.
\end{abstract}

KEYWORDS: Chrysanthemum morifolium, Sodium Azide, Heritability, genotypic coefficient of variation, phenotypic coefficient of variation, expected genetic advance

\section{INTRODUCTION}

Chrysanthemum

(Chrysanthemum morifolium Ramat) which we commonly known as Autumn Queen is one of the most important ornamental plants as cut flowers and pot plants. It is a member of the Asteraceae family and native to Northern hemisphere, chiefly Europe and Asia (Anderson, 1987).

Plant breeding has a vital role in improving several plant traits such as; increase yield, tolerance of environmental stress, resistance to viruses, fungi and bacteria, insect pests, herbicides, longer storage period for the harvested crop, improve shape, size and color for plant flowers. It also used to improve the quality, such as increase nutrition value, flavor, or greater beauty (Poehlman and Sleper, 1995).

For a modern and industrialized floriculture, there is always a demand and necessity for new varieties. Mutagenesis is one of the most applicable methods that use in plant improvement for its features simplicity, technical and economic viability, applicability to all plant species and usability in small or large scales (Siddiqui and Khan, 1999). Sodium azide which creates a point mutation, is an important mutagen to enhance agronomic traits and induce new cultivars of many plants as found by
Gruszka et al. (2012), El mokadem and Mostafa (2014) and Kapadiya et al. (2014)

The possibilities of using mutation breeding in vegetatively propagated plants are favorable for various reasons such as the usually large heterozygosity of the material which allows direct detection of mutations in the treated material. In the vegetatively propagated material, the intention which is often improving visible characteristics and selection of potentially useful mutations is generally easy (Broertjes, 1986).

Therefore, present study was conducted to study the effect of Sodium Azid(SA) treatments on the vegetative and flowering growth of Chrysanthemum morifolium cv. Maghi plants. Also, to evaluate genetic variability of these traits resulted from SA treatments.

\section{MATERIALS AND METHODS}

A pot experiment was carried out at the Nursery of Ornamental Plants, Faculty of Agriculture, Minia University, Minia Governorate during two successive seasons 2015/2016 and 2016/2017.

Shoot apical cuttings (about 13-15 cm long) of C. morifolium cv. Maghi were taken in 10th 


\section{Scientific Journal of Agricultural Sciences 1 (1): 14-20, 2019}

March from healthy plants in both seasons. The bases of cuttings (about $3 \mathrm{~cm}$ ) were dipped in the $\mathrm{SA}$ solution (Sigma Chem. Co., St. Louis, Mo, in three concentrations $(0.0,0.12$ and $0.18 \%)$ for two different soaking times (6 and $12 \mathrm{~h})$. The SA was dissolved on buffer phosphate and the $\mathrm{pH}$ of solution was adjusted at 3 .

Then cuttings were rinsed under running tap water for $10 \mathrm{~min}$. Each 5 cuttings were planted in 10 $\mathrm{cm}$ pot containing mixture of clay and sand $(4: 1 \mathrm{v} / \mathrm{v})$

After 45 days, the development plantlets were transferred into $25-\mathrm{cm}$ pots filled with the same previous growth media. All ordinary agriculture treatments were applied.

The layout of the experiment was Completely Randomized Design (CRD) containing six treatments each contained 180 plants.

The recorded data were as follow survival percentage, plant height $(\mathrm{cm})$, number of main branches, days to bloom, number of flower heads/plant, flower head diameter (FHD) (mm), flower head fresh and dry weights (mg)

Genetic parameters were estimate in both seasons. The magnitude of variance of each mean value, phenotypic $(\sigma 2 \mathrm{P})$ and genotypic $(\sigma 2 \mathrm{G})$ variances, phenotypic coefficient of variation (PCV), genotypic coefficient of variation (GCV) were estimated according to the method advocated by Singh and Chaudhary (1985). GCV and PCV values were categorized as low $(0-10 \%)$, moderate (10$20 \%$ ) and high (above 20) as indicated by Sivasubramanian and Menon (1973).

The expected genetic advance as a percent of mean (GAM) were considered as illustrated by (Panse and Sukhatme, 1967). Heritability in broad sense was determined according to the methodology given by Allard (1960). The heritability was categorized as low (0-30\%), moderate (30-60\%) and high (above 60\%) as given by Robinson et al. (1949).

\section{Results and Discussion}

\subsection{Cuttings survivability percentage}

Survivability percentage of treated cuttings was recorded after a month of SA treatment. The survival percentage was immensely hampered $(\mathrm{P}>0.05)$ due to the SA concentrations and the time of the treatment. Moreover, there was a significant interaction between the concentration and time of treatment as shown in Fig 1. The concentration $0.18 \%$ for $6 \mathrm{~h}$ and $12 \mathrm{~h}$ reduced the survivability to 38 and $43 \%$ in the first season respectively .Moreover, the survivability percentage was significantly lower when cuttings treated with SA at $0.18 \%$ for $6 \mathrm{~h}$ and $12 \mathrm{~h}$ (64 and $50 \%$, respectively). Similar results were observed in the second season.

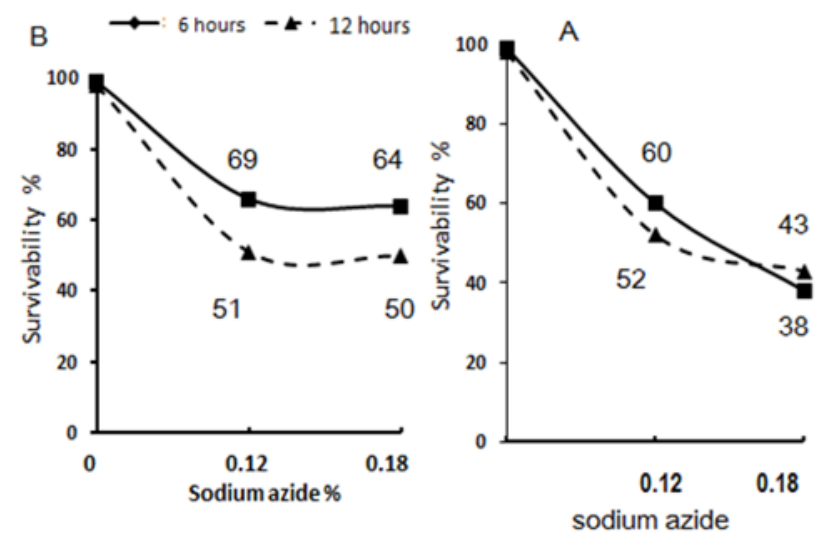

Fig 1. Effect of Sodium Azide on chrysanthemum morifolium cv.Maghi plant cuttings survivability ( $A$ and $B$ in the $1^{\text {st }}$ and $2^{\text {nd }}$ seasons respectively.

These results might be attributed to the expected effect of mutagens on the meristematic tissues which may be due to delay in the beginning of mitosis (Yadav, 1987), physiological and acute chromosomal damage (Singh and Kole, 2005). Zhang (2000) suggested that the effect of SA could be traced to the azide anions that are strong inhibitors of cytochrome oxidase, which in turn inhibits oxidative phosphorylation. In addition, it is a potent inhibitor of the proton pump and alters the mitochondrial membrane potential. Liamngee et al. (2017) suggested that the injurious activity of SA on the root cap cells and the meristematic cells which replace the root cap cells can render it, thus exposing the tender root cells to injury and soil fungi and bacteria which can eventually kill the root hairs. This leaves a high probability for the death of the young seedling.

3.2. Plant height: The shortest significant mean $(52.1 \mathrm{~cm})$ was for the treatment $0.12 \%$ SA for $12 \mathrm{~h}$ although, this treatment included the highest plant $(90 \mathrm{~cm})$ as shown in Table1. In the second season, results indicated that plants treated with $0.12 \% \mathrm{SA}$ for $6 \mathrm{~h}$ gained the highest significant mean in plant height $(89.7 \mathrm{~cm})$. Moreover, significant variations among plant heights were observed due to the treatment. Surely, this wide variation which ranged e.g. from 10 to $122 \mathrm{~cm}$ following the treatment with $0.18 \%$ for $12 \mathrm{~h}$ in the $2^{\text {nd }}$ season caused a higher PCV (34.81), GCV (34.66) and consequences higher heritability and GAM. But in the $1^{\text {st }}$ season, the highest GAM (93.75) was for plants treated with $0.18 \%$ for $6 \mathrm{~h}$ which their height ranged from 17.03 to $19.66 \mathrm{~cm}$.

3.3. Number of branches: The treatments had a significant effect on this trait. All treatments reduced number of branches compared to control especially the treatment of $0.12 \%$ SA for $12 \mathrm{~h}$ (2.31and 3.9 in the $1^{\text {st }}$ and $2^{\text {nd }}$ seasons respectively) as shown in Table 1 . The $\sigma^{2} \mathrm{P}$ and $\sigma^{2} \mathrm{G}$ values were 
Table 1. Some genetic estimates for plant height $(\mathrm{cm})$ and number of branches/plant traits of Chrysanthemum morifolium cv. Maghi following sodium azide treatment during two seasons

\begin{tabular}{|c|c|c|c|c|c|c|c|c|c|c|c|c|c|c|c|c|c|}
\hline \multicolumn{10}{|c|}{ First season } & \multicolumn{8}{|c|}{ Second season } \\
\hline SA \% & Time (h) & Range & Mean & $\sigma^{2} \mathbf{P}$ & $\sigma^{2} \mathbf{G}$ & $\mathbf{P C V}$ & GCV & $\mathbf{H}$ & GAM & Range & Mean & $\sigma^{2} \mathbf{P}$ & $\sigma^{2} G$ & $\mathbf{P C V}$ & GCV & $\mathbf{H}$ & GAM \\
\hline \multicolumn{18}{|c|}{ plant height $(\mathrm{cm})$} \\
\hline \multirow[t]{2}{*}{0.0} & 6 & $55-79$ & 67.1 & 54.26 & 47.14 & 10.89 & 10.23 & 86.88 & 19.66 & $57-80$ & 68.3 & 48.43 & 41.73 & 10.19 & 09.46 & 86.17 & 18.09 \\
\hline & 12 & $55-78$ & 66.8 & 48.85 & 42.73 & 10.56 & 09.78 & 85.72 & 18.66 & $56-79$ & 67.4 & 43.41 & 36.71 & 09.77 & 08.98 & 84.57 & 17.03 \\
\hline \multirow[t]{2}{*}{0.12} & 6 & $15-80$ & 60.5 & 251.39 & 244.3 & 26.19 & 25.82 & 97.17 & 52.44 & 15-137 & 89.7 & 563.79 & $\mathbf{5 5 7 . 1 0}$ & 26.48 & 26.32 & 98.81 & 53.91 \\
\hline & 12 & 23-90 & 52.1 & 253.51 & 246.4 & 30.57 & 30.14 & 97.19 & 61.22 & $35-138$ & 78.3 & 434.76 & 428.10 & 26.61 & 26.41 & 98.46 & 53.99 \\
\hline \multirow[t]{2}{*}{0.18} & 6 & 17-88 & 54.2 & 622.82 & 615.7 & 46.03 & 45.77 & 98.86 & 93.75 & 25-125 & 85.7 & 691.09 & 684.40 & 30.66 & 30.51 & 99.03 & 62.56 \\
\hline & 12 & $30-90$ & 68.5 & 212.72 & 205.6 & 21.31 & 20.94 & 96.65 & 42.42 & $10-122$ & 77.8 & 734.42 & 727.70 & 34.81 & 34.66 & 99.09 & 71.07 \\
\hline \multicolumn{18}{|c|}{ Number of branches/plant } \\
\hline \multirow[t]{2}{*}{0.0} & 6 & $1-8$ & 4.6 & 03.83 & 01.72 & 44.03 & 29.47 & 44.79 & 40.63 & $1-7$ & 4.9 & 3.27 & 1.41 & 36.90 & 24.23 & 43.12 & 32.78 \\
\hline & 12 & $2-9$ & 5.6 & 04.67 & 02.55 & 38.58 & 28.51 & 54.60 & 43.41 & $1-8$ & 4.6 & 3.83 & 1.97 & 42.54 & 30.51 & 51.44 & 45.07 \\
\hline \multirow[t]{2}{*}{0.12} & 6 & $1-16$ & 8.4 & 16.75 & 14.63 & 48.89 & 45.69 & 87.34 & 87.97 & $1-8$ & 3.12 & 3.25 & 1.39 & 57.78 & 37.78 & 42.77 & 50.90 \\
\hline & 12 & $1-14$ & 3.9 & 11.21 & 09.09 & 84.76 & 76.32 & 81.09 & 141.58 & $1-7$ & 2.31 & 2.25 & 0.39 & 64.93 & 27.03 & 17.33 & 23.18 \\
\hline \multirow[t]{2}{*}{0.18} & 6 & $1-13$ & 5.9 & 14.54 & 12.42 & 63.97 & 59.13 & 85.42 & 112.57 & $1-6$ & 2.62 & 2.19 & 0.33 & 56.48 & 21.92 & 15.07 & 17.53 \\
\hline & 12 & $1-12$ & 6.9 & 10.71 & 08.59 & 47.63 & 42.66 & 80.21 & 78.71 & $1-10$ & 3.12 & 5.71 & 3.85 & 76.58 & 62.88 & 67.43 & 106.37 \\
\hline
\end{tabular}

LSD 5\%: $\left(1^{\text {st }}\right.$ season: 17.68 and1.67, $2^{\text {nd }}$ season: 9.1 and 1.67 for plant height and number of branches per plant respectively). $\boldsymbol{\sigma}^{2} \mathbf{P}$ : Phenotypic variances; $\boldsymbol{\sigma}^{\mathbf{2}}$ : Genotypic variances; PCV: Phenotypic coefficient of variance; GCV: Genotypic coefficient of variance; H: Heritability; GAM: Genetic advance as a percent of mean.

noticeably differed among plants in both seasons. In the 1st one the control plants had very low $\sigma 2 \mathrm{P}$ and $\sigma 2 \mathrm{G}$ values (3.48 - 4.67 and $1.72-2.55$, respectively) however the SA-treated plants had $\sigma 2 \mathrm{P}$ and $\sigma 2 \mathrm{G}$ values of (10.71-16.75) and (8.59-14.63) respectively In the 2 nd season the control plants had similar values for that of the 1st one but these values were reduced to (2.19-5.71) and (0.33-3.85) for $\sigma 2 \mathrm{P}$ and $\sigma 2 \mathrm{G}$ respectively $\mathrm{The} H$ could be considering as high for SA-treated plant in the 1st season as well as the treatment $0.18 \% \mathrm{SA}$ for $12 \mathrm{~h}$ in the $2 \mathrm{nd}$ season. But in the 2nd season, the plants treated with $0.12 \%$ SA for $12 \mathrm{~h}$ as well as $0.18 \%$ for $6 \mathrm{~h}$ had a moderate $\mathrm{H}$. These two treatments had low GAM (23.18 and 17.53) respectively, however the other SA treated plants had GAM varied between 50.9 and 141.58 depending on the concentration and time of treatment.

3.4. Days to bloom: The number of days till bloom was significantly varied among the treatments in both seasons as shown in Table2. In the $1^{\text {st }}$ season only plants treated with $0.12 \%$ SA for $12 \mathrm{~h}$ flowered late. There was a noticeable difference between the two seasons where the range was 211-258 days with a mean of 217.3-230.58 days in the $1^{\text {st }}$ one and 224279 days with a mean of 243.76-254.50 days in the second one. The PCV and GCV were low for all plants. Although, the $\mathrm{H}$ could classified as high the GAM was very low.

3.5. Number of flower heads/plant: The control plants had number of flower heads were ranged between 12 and 26 with a mean of (17.5-19.4). Table 2 shows a significant effect of SA-treatments on number of flower heads/plant. For example some treatment prevented flower heads development. In the $1^{\text {st }}$ season the SA-treated plant had a mean number of flower heads less than that of the control plants. However, in the $2^{\text {nd }}$ one plants treated with $(0.12 \%$ SA for $6 \mathrm{~h})$ and $(0.18 \%$ SA for $6 \mathrm{~h})$ had a higher mean number of flower heads (23.9 and 19.7, respectively) than that of the control plants.

The $\sigma^{2} \mathrm{P}$ and $\sigma^{2} \mathrm{G}$ values of SA-treated plants were quite higher than that of the control plants especially in the $2^{\text {nd }}$ season. The PCV and GCV of SA-treated plant were higher however; these values were moderate for the control ones. The highest PCV and GCV value were observed in the $1^{\text {st }}$ season for plants treated with $0.12 \% \mathrm{SA}$ for $12 \mathrm{~h}$. The $\mathrm{H}$ values of the number of flower heads were high for all plants and varied between 62.63 and 98.49. Although, the GAM was considered as high for all SA-plants even the control ones, some of them had GAM values higher than 100 but the equivalent value for the control plants was (20.85-34-82). 
Table 2. Some genetic estimates for number of days to flower and number of flower heads/plant traits of Chrysanthemum morifolium cv. Maghi following sodium azide treatment during two seasons

\begin{tabular}{|c|c|c|c|c|c|c|c|c|c|c|c|c|c|c|c|c|c|}
\hline \multicolumn{10}{|c|}{ First season } & \multicolumn{8}{|c|}{ Second season } \\
\hline SA \% & Time (h) & Range & Mean & $\sigma^{2} \mathbf{P}$ & $\sigma^{2} G$ & PCV & GCV & $\mathbf{H}$ & GAM & Range & Mean & $\sigma^{2} \mathbf{P}$ & $\sigma^{2} G$ & PCV & GCV & $\mathbf{H}$ & GAM \\
\hline \multicolumn{18}{|c|}{ Number of days to flower } \\
\hline \multirow[t]{2}{*}{$\mathbf{0 . 0}$} & 6 & $211-230$ & 217.30 & 27.06 & 21.71 & 2.39 & 2.14 & 80.23 & 03.96 & $232-247$ & 239.3 & 17.88 & 13.67 & 1.77 & 1.55 & 76.45 & 2.78 \\
\hline & 12 & 212-232 & 218.50 & 31.11 & 25.76 & 2.55 & 2.32 & 82.80 & 04.35 & 232-249 & 239.8 & 18.51 & 14.30 & 1.79 & 1.58 & 77.26 & 2.85 \\
\hline \multirow[t]{2}{*}{0.12} & 6 & 211-234 & 217.94 & 40.56 & 35.21 & 2.92 & 2.72 & 86.81 & 05.23 & $235-255$ & 241.9 & 20.06 & 15.85 & 1.85 & 1.65 & 79.01 & 3.01 \\
\hline & 12 & 212-258 & 230.58 & 135.67 & 130.30 & 5.05 & 4.95 & 96.06 & 10.00 & $235-253$ & 241.0 & 36.72 & 32.51 & 2.51 & 2.37 & 88.53 & 4.58 \\
\hline \multirow[t]{2}{*}{0.18} & 6 & 211-231 & 218.42 & 61.14 & 55.79 & 3.58 & 3.42 & 91.25 & 06.73 & $235-255$ & 240.4 & 24.59 & 20.38 & 2.06 & 1.88 & 82.88 & 3.52 \\
\hline & 12 & 211-241 & 222.78 & 99.35 & 94.00 & 4.47 & 4.35 & 94.61 & 08.72 & $235-253$ & 239.0 & 18.42 & 14.21 & 1.80 & 1.58 & 77.14 & 2.85 \\
\hline \multicolumn{18}{|c|}{ Number of flower heads/plant } \\
\hline \multirow[t]{2}{*}{0.0} & 6 & $15.0-26$ & 19.4 & 11.72 & $\mathbf{0 8 . 3 6}$ & 17.64 & 14.90 & 71.33 & 25.93 & $12-25$ & $\mathbf{1 7 . 5}$ & 15.11 & 11.50 & 22.21 & 19.37 & 76.11 & 34.82 \\
\hline & 12 & $16.0-24$ & 18.6 & 08.99 & 05.63 & 16.16 & 12.79 & 62.63 & 20.85 & 13.24 & 17.9 & 11.67 & 08.10 & 19.08 & 15.86 & 69.07 & 27.15 \\
\hline \multirow[t]{2}{*}{0.12} & 6 & $0.0-26$ & 13.22 & 41.28 & 37.92 & 48.60 & 46.58 & 91.86 & 91.96 & $0.0-76$ & 23.8 & 238.89 & 235.30 & 64.69 & 64.21 & 98.49 & 131.26 \\
\hline & 12 & $0.0-23$ & 07.14 & 45.09 & 41.73 & 94.04 & 90.47 & 92.55 & 179.29 & $0.0-48$ & 11.4 & 85.02 & 81.41 & 80.88 & 79.14 & 95.75 & 159.54 \\
\hline \multirow[t]{2}{*}{0.18} & 6 & $0.0-33$ & 12.22 & 79.34 & 75.98 & 72.89 & 71.33 & 95.77 & 143.79 & $0.0-43$ & 19.7 & 211.74 & 208.10 & 73.52 & 72.89 & 98.30 & 148.88 \\
\hline & 12 & $0.0-30$ & 11.93 & 44.99 & 41.63 & 56.22 & 54.08 & 92.53 & 107.17 & $0.0-41$ & 14.1 & 131.38 & 127.80 & 81.17 & 80.05 & 97.25 & 162.62 \\
\hline
\end{tabular}

LSD 5\%: $\left(1^{\text {st }}\right.$ season: $4.283 .09,2^{\text {nd }}$ season: 3.72 and 5.0.for numbers of days to flower and flower heads/plant respectively). $\boldsymbol{\sigma}^{2} \mathbf{P}$ : Phenotypic variances; $\boldsymbol{\sigma}^{2} \mathbf{G}$ : Genotypic variances; PCV: Phenotypic coefficient of variance; GCV: Genotypic coefficient of variance; H: Heritability; GAM: Genetic advance as a percent of mean.

Table 3: Some genetic estimates for flower head diameter ( $\mathrm{mm})$ trait of Chrysanthemum morifolium cv. Maghi following sodium azide treatment during two seasons

\begin{tabular}{|c|c|c|c|c|c|c|c|c|c|c|c|c|c|c|c|c|c|}
\hline \multicolumn{10}{|c|}{ First season } & \multicolumn{8}{|c|}{ Second season } \\
\hline SA \% & Time (h) & Range & Mean & $\sigma^{2} \mathbf{P}$ & $\sigma^{2} G$ & PCV & GCV & $\mathbf{H}$ & GAM & Range & Mean & $\sigma^{2} \mathbf{P}$ & $\sigma^{2} G$ & PCV & GCV & $\mathbf{H}$ & GAM \\
\hline \multirow[t]{2}{*}{0.0} & 6 & $65.4-74.2$ & 70.2 & 11.06 & 07.89 & 04.74 & 04.00 & 71.34 & 06.96 & 64.8-75.4 & 69.8 & 15.43 & 11.8 & 05.62 & 04.92 & 76.47 & 08.86 \\
\hline & 12 & $64.5-73.3$ & 69.4 & 10.85 & 07.68 & 04.75 & 03.99 & 70.78 & 06.92 & $64.5-74.4$ & 69.9 & 11.66 & 08.0 & 04.88 & 04.05 & 68.87 & 06.93 \\
\hline \multirow[t]{2}{*}{0.12} & 6 & 49.7-99.2 & 74.7 & 105.75 & 102.6 & 13.76 & 13.55 & 97.00 & 27.50 & $52.0-104.6$ & 76.4 & 67.91 & 64.28 & 10.78 & 10.49 & 94.65 & 21.03 \\
\hline & 12 & 54.5-68.0 & 72.1 & 74.88 & 71.71 & 12.00 & 11.74 & 95.77 & 23.67 & 70.7-104 & 84.2 & 48.56 & 44.93 & 08.27 & 07.95 & 92.52 & 15.77 \\
\hline \multirow[t]{2}{*}{0.18} & 6 & $60.2-89.5$ & 76.3 & 59.55 & 56.38 & 10.11 & 09.84 & 94.68 & 19.72 & 65.6-91.6 & 81.6 & 34.58 & 30.95 & 07.20 & 06.81 & 89.50 & 13.27 \\
\hline & 12 & $66.2-95.2$ & 79.9 & 54.21 & 51.04 & 09.21 & 08.93 & 94.15 & 17.86 & $60.2-97.2$ & 82.9 & 49.34 & 45.71 & 08.47 & 08.15 & 92.64 & 16.16 \\
\hline
\end{tabular}

LSD 5\%: (for $1^{\text {st }}$ season: 4.67 and for the $2^{\text {nd }}$ season: 3.00 plant height and number of branches per plant). $\boldsymbol{\sigma}^{2} \mathbf{P}$ : Phenotypic variances; $\boldsymbol{\sigma}^{2} \mathbf{G}$ : Genotypic variances; PCV: Phenotypic coefficient of variance; GCV: Genotypic coefficient of variance; H: Heritability; GAM: Genetic advance as a percent of mean.

\subsection{Flower head diameters (FHD):}

The control plants had a mean FHD about $70 \mathrm{~mm}$ in both seasons with a range of 64.5-75.4 $\mathrm{mm}$ as shown in Table 3. On some cases such as plants treated with $0.12 \%$ SA for 6 h their FHD (49.7-99.2 and 52.0-104.6 $\mathrm{mm}$ ) in both seasons, respectively) was wider than that of the control plants. However, the disparity of the FHD was not too high between the control plants (69.4 and 70.2 $\mathrm{mm})$ and the SA-treated plants (72.1-84.2 $\mathrm{mm}$ ). Overall, the control plants had the lowest $\sigma^{2} \mathrm{P}$ (10.85-15.43) and $\sigma^{2} \mathrm{G}(7.68-11.8)$ but there were a substantial increase on these values following some of SA treatments. For example, the treatment $0.12 \%$ SA for $6 \mathrm{~h}$ had $\sigma^{2} \mathrm{P}\left(105.75\right.$ and 110.95) and $\sigma^{2} \mathrm{G}$ (102.6 and 107.3) in both seasons, respectively. The PCV and GCV were low (less than 10). Nevertheless, the control plants had very low PCV and GCV (4.0-5.62). Although, all plants had a high $\mathrm{H}$ value, the GAM of the control plants were very low (6.92-8.86) but it was ranged from 13.27 to 27.5 for SA-treated plants depending on the concentration and time of treatment.

\subsection{Flower head fresh weights (FHFW):}

The FHFW of control plants was ranged between 2.24 and $3.68 \mathrm{~g} / \mathrm{head}$ with a mean of 2.61- 


\section{A-H. Mohamed et al., 2019}

$2.86 \mathrm{~g} / \mathrm{head}$ in the $1^{\text {st }}$ season with slightly differ in the $2^{\text {nd }}$ one as shown in Table 4 . In the $2^{\text {nd }}$ season, plants treated with $0.18 \%$ SA for $6 \mathrm{~h}$ had a mean FHFW (2.83g). Although, their FHFW was varied between 0.85 and $6.4 \mathrm{~g} / \mathrm{head}$. However, the analysis of variance showed no significant difference on FHFW among the treatments in both seasons.

The $\sigma^{2} \mathrm{P}$ and $\sigma^{2} \mathrm{G}$ values were strangely increased when plants treated with SA to reach the maximum value 9.01 and 8.69 , respectively once plants treated with $0.18 \% \mathrm{SA}$ for $6 \mathrm{~h}$ in the $2^{\text {nd }}$ season. However, the equivalent values for the control were 0.91 and 0.58. All investigated plants in both seasons had low PCV, GCV and H.

\subsection{Flower head dry weights (FHDW)}

The FHDW of the control plants was varied between 230 and $520 \mathrm{mg} / \mathrm{head}$ but SA treatment shifted this variation to 200 and $760 \mathrm{mg} / \mathrm{plant}$ as shown in Table 4 . The highest significant FHDW mean $(520.4 \mathrm{mg} / \mathrm{head})$ was observed in the $1^{\text {st }}$ season when plants treated with $0.18 \%$ SA for $12 \mathrm{~h}$ however, this mean reduced to $396.7 \mathrm{mg} / \mathrm{head}$ in the 2nd season. In that season the treatment $0.12 \%$ SA for $12 \mathrm{~h}$ had the highest significant value (431.4 $\mathrm{mg} / \mathrm{head})$. The PCV and GCV of control plants were moderate for both seasons. However, these parameters were high for all SA-treated plants; similarly, the $\mathrm{H}$ and GAM were high for all treatment.

The effect of SA on plant growth could be due to its ion influence which hinders the latter part of the electron transfer chain or inhibition of catalase, peroxidase, and cytochrome oxidation which affects the respiratory process (Gruszka et al., 2012). Alteration on growth may be attributed to (i) the increase in growth promoters, (ii) the sudden rise in metabolic status at certain levels of dose, (iii) the increase in destruction of growth inhibitors and (iv) drop in the auxin level or inhibition of auxin synthesis (Roychowdhury and Tah, 2011). In addition, inhibition of enzymes activity that catalyzes the biosynthesis of gibberellins which play a role in stem elongation probably was also affected (Dewi et al., 2016).

High GCV of many assessed traits for both Chrysanthemum genotypes suggested that these characters are under influence of genetic control. Hence, simple selection can be relied upon and practiced for further improvement of these characters. These results are in consonance with Nimbalikar et al. (2007), Lepecha et al. (2007), (Kumar et al., 2011) on gladiolus, Roychowdhury and Tah (2011) on carnation Singh et al. (2014). Higher estimates of heritability with genetic advance as per cent of mean were observed for many traits following SA treatments indicating the presence of additive gene action and so selection can be easily done for these traits. The trait which expressed high heritability and low genetic advance showed non additive gene interaction, hence heterosis breeding would be recommended for that trait (Roychowdhury and Tah, 2011).

Table 4: Some genetic estimates for Flower head fresh weights (g) and Flower head dry weights(mg) traits of Chrysanthemum morifolium cv. Maghi following sodium azide treatment during two seasons

\begin{tabular}{|c|c|c|c|c|c|c|c|c|c|c|c|c|c|c|c|c|c|}
\hline \multicolumn{10}{|c|}{ First season } & \multicolumn{8}{|c|}{ Second season } \\
\hline SA \% & Time (h) & Range & Mean & $\sigma^{2} \mathbf{P}$ & $\sigma^{2} \mathbf{G}$ & PCV & GCV & $\mathbf{H}$ & GAM & Range & Mean & $\sigma^{2} \mathbf{P}$ & $\sigma^{2} \mathbf{G}$ & PCV & GCV & $\mathbf{H}$ & GAM \\
\hline \multicolumn{18}{|c|}{ Flower head fresh weights (g) } \\
\hline \multirow[t]{2}{*}{$\mathbf{0 . 0}$} & 6 & 2.24-3.47 & 2.86 & 2.18 & 1.74 & 1.63 & 1.45 & 7.96 & 2.68 & 2.51-3.57 & 2.98 & 1.20 & 0.88 & 1.16 & 0.99 & 7.33 & 1.75 \\
\hline & 12 & 2.34-3.68 & 2.61 & 1.74 & 1.30 & 1.59 & 1.38 & 7.45 & 2.45 & 2.64-3.45 & 3.10 & 0.91 & 0.58 & 0.97 & 0.78 & 6.46 & 1.29 \\
\hline \multirow[t]{2}{*}{0.12} & 6 & 2.44-5.04 & 3.50 & 4.22 & 3.78 & 1.85 & 1.75 & 8.95 & 3.41 & $1.64-4.44$ & 2.93 & 4.20 & 3.88 & 2.21 & 2.12 & 9.23 & 4.20 \\
\hline & 12 & $1.65-4.91$ & 2.77 & 4.99 & 4.54 & 2.55 & 2.43 & 9.11 & 4.78 & $1.28-4.93$ & 3.18 & 6.71 & 6.39 & 2.57 & 2.51 & 9.52 & 5.04 \\
\hline \multirow[t]{2}{*}{0.18} & 6 & 2.14-4.61 & 3.63 & 3.94 & 3.49 & 1.72 & 1.62 & 8.87 & 3.15 & $0.85-6.40$ & 2.83 & 9.01 & 8.69 & 3.34 & 3.28 & 9.64 & 6.64 \\
\hline & 12 & 2.48-5.85 & 3.91 & 5.95 & 5.50 & 1.96 & 1.89 & 9.25 & 3.75 & $1.85-5.05$ & 3.22 & 4.97 & 4.65 & 2.18 & 2.11 & 9.35 & 4.21 \\
\hline \multicolumn{18}{|c|}{ Flower head dry weights(mg) } \\
\hline \multirow[t]{2}{*}{0.0} & 6 & $240-390$ & 334.0 & 1931.32 & 1886.00 & 13.15 & 13.00 & 97.67 & 26.47 & $340-510$ & 420.5 & 2383.94 & 2337.00 & 11.61 & 11.49 & 98.05 & 23.45 \\
\hline & 12 & 230-390 & 327.5 & 2198.68 & 2154.00 & 14.31 & 14.17 & 97.95 & 28.89 & $330-520$ & 414.5 & 2036.57 & 1990.00 & 10.88 & 10.76 & 97.72 & 21.91 \\
\hline \multirow[t]{2}{*}{0.12} & 6 & 290-700 & 475.1 & 11856.24 & 11811.00 & 41.30 & 41.27 & 99.62 & 47.03 & $200-650$ & 388.6 & 7495.24 & 7449.00 & 22.27 & 22.21 & 99.38 & 45.60 \\
\hline & 12 & $230-640$ & 403.4 & 12909.11 & 12864.00 & 80.51 & 80.46 & 99.65 & 57.81 & $280-720$ & 431.4 & 18583.70 & 18537.00 & 31.59 & 31.56 & 99.75 & 64.93 \\
\hline \multirow[t]{2}{*}{0.18} & 6 & $290-760$ & 494.2 & 17268.84 & 17224.00 & 66.13 & 66.11 & 99.74 & 54.63 & $220-570$ & 382.8 & 7397.55 & 7351.00 & 22.46 & 22.39 & 99.37 & 45.98 \\
\hline & 12 & $350-690$ & 520.4 & 9736.91 & 9692.00 & 38.77 & 38.75 & 99.54 & 38.88 & $240-650$ & 396.7 & 1229.60 & 12247.00 & 27.94 & 27.89 & 99.62 & $\mathbf{5 7 . 3 5}$ \\
\hline
\end{tabular}

LSD 5\%: $\left(1^{\text {st }}\right.$ season: NS and53.21, $2^{\text {nd }}$ season: NS and 15.5 for fresh and dry weight of vegetative growth respectively). $\boldsymbol{\sigma}^{2} \mathbf{P}$ : Phenotypic variances; $\boldsymbol{\sigma}^{2}$ G: Genotypic variances; PCV: Phenotypic coefficient of variance; GCV: Genotypic coefficient of variance; H: Heritability; GAM: Genetic advance as a percent of mean. 


\section{REFERENCES}

Allard RW (1960). Principles of Plant Breeding. New York, John Wiley and sons, Inc. P.185

Anderson RL (1987). Reclassification of genus Chrysanthemum. Hort. Science, 22:313.

Broertjes C (1986). Mutation breeding of vegetatively propagated crop. In Mutation in Plant Breeding, Proceeding. FAO/IAEA, Milan, Italy, Pp 139-165.

Dewi K, Meidana G, Sudjino S (2016). Effects of sodium azide $(\mathrm{NaN} 3)$ and cytokininon vegetative growth and yield of black rice plant (Oryza sativa $\mathrm{L}$. 'Cempo Ireng'). AIP Conference Proceedings, Earth and Environmental Science, 102

El-Mokadem Hoda E, Mostafa Gehan G (2014). Induction of mutations in Browallia speciosa using sodium azide and identification of the genetic variation by peroxidase isozyme. African $\mathrm{J}$. of Biotechnology, 13(1): 106-111

Gruszka D, Szarejko I, Maluszynski M (2012). Sodium azide as mutagen. In: Plant Mutation Breeding and Biotechnology. CABI International, Willing ford, UK, Pp. 159-166

Kapadiya DB, Chawla SL, Patel AL Ahlawat TR (2014). Exploitation of variability through mutagenesis in Chrysanthemum (Chrysanthemum morifolium Ramat.) var. Maghi, Journal of Life Sci., 9(4):1799-1804

Kumar P, Maurya R K, Chakraborty B, Mer, R, Mishra DS (2011). Genetic variability and correlation studies in Gladiolus hybrida L. under tarai condition. Ann. Hort, 4: 140-146.

Lepecha B, Nautiyal MC, Rao VK (2007). Variability studies in gladiolus under mid hill conditions of Uttarakh. J. Ornamental. Horticulture, 10: 169-172.

Liamngee SM, Ogah J J, Amagu KT, KwonNdung EH, Iorkor D, Tervershima JE (2017). Mutagenic action of sodium azide on germination and emergence in landraces of Phaseolus vulgaris $\mathrm{L}$. on the Jos Plateau Agro-Ecological Zone, J. of Agriculture and Veterinary Sci., 10(2): 64-70.
Nimbalikar CA, Katwate SM, .Singh BR, .Kakade DS, Gurav SB (2007). Selection strategy for improvement in economic traits of Gladiolus. J. Ornamental Horticulture, 10 (1): 9-14.

Poehlman JM, Sleper DA (1995). Breeding Field Crops. Ames, IA: Iowa State University Press.

Panse VG, Sukhatme PV (1967). Statistical methods for agricultural workers (2nd Ed.). ICAR publication, New Delhi. 381 p.

Robinson HF, Johnson HW, Comstock R.E (1949). Estimates of genetic and environmental variability in soybean. J. Agronomy, 17: 28-36.

Roychowdhury R, Tah J (2011). Chemical mutagenic action on seed germination and related agro-metrical traits in M1 Dianthus generation. Current. Botany, 2 (8): 19-23.

Siddiqui BA, Khan S (1999). Breeding in crop plants: mutations and in vitro mutation breeding. Kalyani, India, p402.

Singh RK , Chaudhary BD (1985). Biometrical methods in quantitative genetic analysis. Kalyani Publishers, Ludhiana, p.318

Singh R, Kole CR (2005). Effect of mutagenic treatments with EMS on germination and some seedling parameters in mung bean . Crop Research, 30 (2): 236-240.

Singh PK, Raju DVS, Banyal N, Janakiram T (2014). Determination of genetic variation for vegetative and floral traits in African marigold (Tagetes erecta). Indian J. of Agricultural Sciences, 84 (9): 1057-1062.

Sivasubramanian S, Menon M (1973). Heterosis and inbreeding depression in rice Madras Agriculture J., 60: 274-277.

Yadav RDS (1987). Effect of mutagens on mitotic index, seedling vigour and chlorophyll mutation in mung bean (Vigna radiata L. Wilczek). J. of Nuclear Agriculture and Biology, 16(1): 13-17.

Zhang BH (2000). Regulation of plant growth regulators on cotton somatic embryogenesis and plant regeneration Biochemistry, 39: 156. 


\section{الملخص العربى}

\section{تقييم نباتات الاراولا صنف Maghi المعاملة بالصوديوم أزيد}

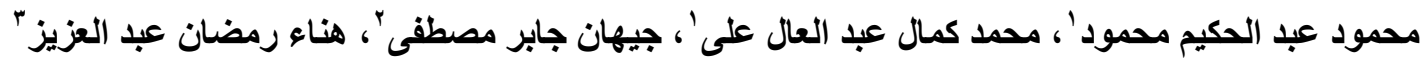

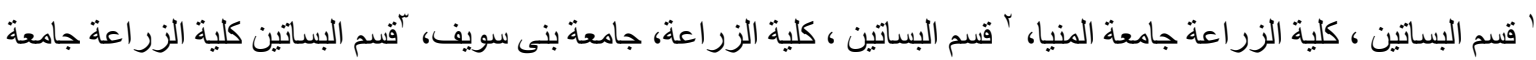

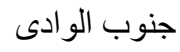

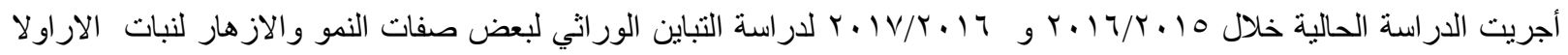

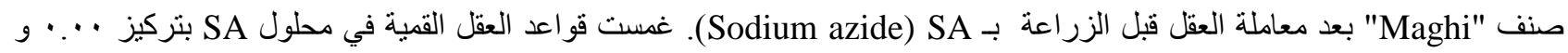

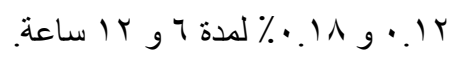

إنخفضت قدرة النباتات على البقاء نتيجة المعاملة بالصوديوم أزيد و اختلفت وفقا للتركيز و فترة النقع. ظهرت تباينات واضحة فى التى

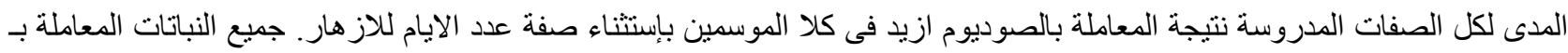
كانت أعلى فى معامل التباين المظرى PCVA و معامل التباين الور اثى GCV مقارنة بالنباتات غير المعاملة لجميع الصفات بإستثناء

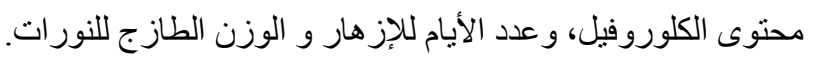

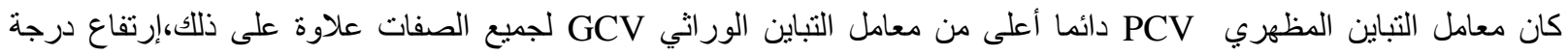
التوريث لكل الصفات مع وجود إختلافات فى درجة التوريث ما بين النباتات المعاملة و غير المعاملة. وجود فرق بسيط بين معامل تباين الثكل المظرى و معامل التباين الور اثى يثير للتأثير الضعيف للبيئة على الصفات الدرروسة و التى تعطى مجال و اسع للانتخاب للطفرات المتفوقة 